\title{
Ovine mitochondrial DNA: mapping and sequencing data in comparison with bovine mtDNA
}

\author{
S Hiendleder, W Hecht, R Wassmuth \\ Institut fuer Tierzucht und Haustiergenetik \\ der Justus-Liebig-Universitaet, Gießen, Germany
}

(Proceedings of the 9th European Colloquium on Cytogenetics of Domestic Animals;

Toulouse-Auzeville, 10-13 July 1990)

mtDNA / evolutionary relationship / sheep / cow

\section{INTRODUCTION}

Mitochondrial DNA (mtDNA) is maternally inherited (Gyllensten et al, 1985) and evolves 5-10 times faster than single-copy nuclear DNA in mammals (Brown et al, 1979). These properties make mtDNA an excellent tool for analyzing evolutionary relationships (Wilson et al, 1985).

We studied the mtDNA structure of Ovis aries and compared it to the Bos taurus (Anderson et al, 1982) sequence.

\section{MATERIALS AND METHODS}

mtDNA was prepared from the liver of a single Merinolandschaf, using the method described by Hecht et al (1988). Restriction endonucleases ( $E c o$ RI, EcoRV, BamHI, $B g l \mathrm{II}$, HindIII, HincII, KpnI, PstI and XbaI) were used according to the manufacturers' recommendations. DNA fragments were separated in $1 \%$ agarose gels, stained with ethidium bromide, photographed and transferred onto Hybond-NNylon membranes (Amersham product information). Hybridization analysis was performed using a $\left[{ }^{32} \mathrm{P}\right] \mathrm{dCTP}-\mathrm{labeled}$ (Sambrook et al, 1989) $2.5 \mathrm{~kb}$ HindIII fragment of porcine mtDNA, encompassing parts of the ATPase6 and ND4 genes and the complete COIII, ND3 and ND4L genes. Two 2.6 and $3.4 \mathrm{~kb} E$ coRI fragments of ovine mtDNA were isolated on diethylaminoethyl (DEAE) membrane filters, cloned into puc13 and the ligation products used to tranform $E$ coli (JM83) (Sambrook et al, 1989). Plasmid DNA for dideoxysequencing was prepared as described in the Diagen Application Protocol (1988). ${ }^{35}$ S-Sequencing reactions were performed with the $\mathrm{T}_{7}$-sequencing kit supplied by Pharmacia according to the manufacturers' instructions. Cronex X-ray film (Dupont) was used for autoradiographs. 


\section{RESULTS AND DISCUSSION}

Total ovine mtDNA as well as cloned fragments were used to map 28 cleavage sites produced by EcoRI, EcoRV, BamHI, BgIII, HindIII, HincII and $X b a I$ by the double-digestion method. Hybridization analysis with a fragment of porcine mtDNA of known gene content along with sequencing data was used for orientation of the map along the bovine sequence (Anderson et al, 1982). The 9 enzymes (PstI and $K p n I$ apparently do not cut ovine mtDNA) used, have a total of 31 recognition sites in bovine mtDNA (there is no EcoRV site in bovine mtDNA). Of the 28 restriction sites observed in the ovine sequence, only 11 are assumed to be present in the bovine sequence (fig 1). The proportion of sites shared is expected to decline as the organisms' DNA sequences diverge. The application of equations 10 and 8 from Nei and $\mathrm{Li}(1979)$ to these data yields an estimated sequence divergence of $16.4 \%$ between the two species.

Sequencing analysis of the terminals of 2 cloned fragments yielded $1.105 \mathrm{~kb}$ of sequence information from ovine mtDNA. Genes partially sequenced were ND5, Cyt.b, ATPase6 and COIII. The comparison of nucleotide and predicted amino acid sequences of the 2 species revealed a clustering of replacement nucleotide substitutions within parts of the sequenced regions of the ND5 (fig 2), Cyt.b and COIII genes (data not shown). Silent substitutions on the other hand seem to be distributed evenly across the sequences. Gene-specific and overall sequence differences are given in table I. The 4 genes showed almost the same rate of nucleotide substitutions, although the COIII (76-79\%) and Cyt.b genes (73-74\%) were more conserved than the ND5 gene (65-71\%), for example, when compared between mouse, cow and human (Anderson et al, 1981, 1982; Bibb et al, 1981). This was probably a result of partial analysis of the genes. Amino acid replacements were highest in the ND5 gene. The lack of any amino acid replacements in the short stretch of ATPase6 DNA was probably due to the high conservation of this region within the group of species mentioned above.

Table I. Sequence differences between ovine and bovine mtDNAs at the nucleotide and predicted amino acid levels.

\begin{tabular}{|c|c|c|c|c|c|c|}
\hline \multirow[t]{3}{*}{ Gene } & \multirow{3}{*}{$\begin{array}{l}\text { Nucleotides } \\
\text { sequenced }\end{array}$} & \multirow[t]{3}{*}{$\%$ of gene } & \multicolumn{2}{|c|}{ Nucleotide substitutions } & \multirow{2}{*}{\multicolumn{2}{|c|}{$\begin{array}{l}\text { Amino acid } \\
\text { substitutions }\end{array}$}} \\
\hline & & & \multirow{2}{*}{$n$} & \multirow{2}{*}{$\%$} & & \\
\hline & & & & & $n$ & $\%$ \\
\hline ATPase6 & 74 & 10.9 & 11 & 14.9 & 0 & 0 \\
\hline COIII & 193 & 24.7 & 30 & 15.5 & 5 & 7.8 \\
\hline Cyt.b & 279 & 24.6 & 43 & 15.4 & 6 & 6.5 \\
\hline ND5 & 559 & 30.8 & 86 & 15.4 & 16 & 8.6 \\
\hline total & 1105 & $6.7^{\mathrm{a}}$ & 170 & 15.4 & 27 & 7.3 \\
\hline
\end{tabular}

a) $\%$ of mt genome.

More than $80 \%$ of all nucleotide replacements were transitions. This is in accordance with results obtained by Wilson et al (1985) in primates. 


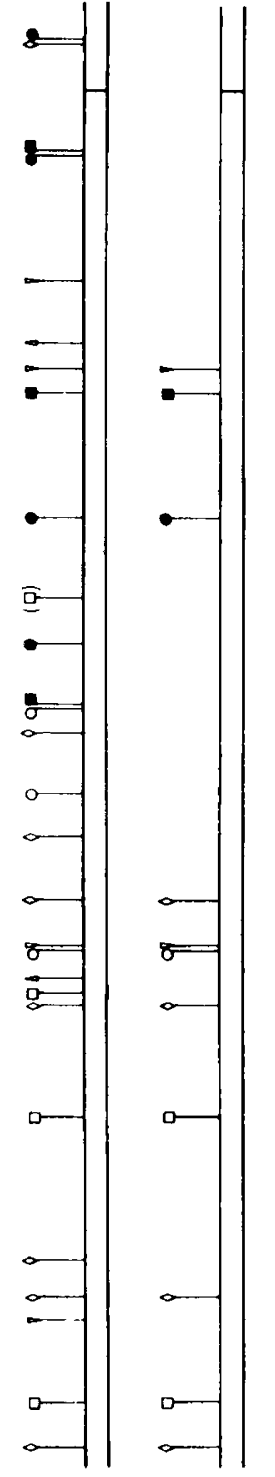

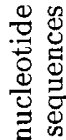
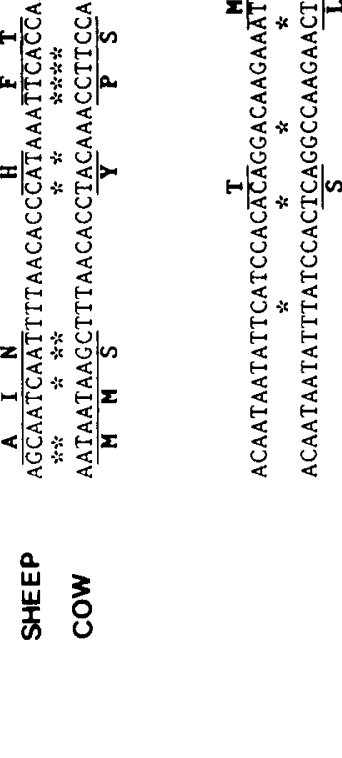

8 국

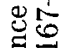


The overall sequence difference of $15.4 \%$ at the nucleotide level corresponds well with $16.4 \%$ sequence divergence calculated from restriction map comparison. Using the data reported by Wilson et al (1985), sheep and cow would have evolved from a common ancestor $7.7-16.4 \times 10^{6}$ years ago.

An example illustrating the limitations inherent in the comparison of restriction mapping data is a BglII site, assumed to be identical in the ovine and bovine maps, which corresponds to bovine nucleotide no 12706 according to Anderson et al (1982). The recognition site in the bovine sequence is actually not identical to the ovine site as shown in figure 1 , but 5 nucleotides downstream from it. Taking this into account, the calculated sequence divergence is $18 \%$ according to Nei and $\mathrm{Li}$ (1979), which results in $9.0-18.0 \times 10^{6}$ years as the time of divergence between the two species.

\section{REFERENCES}

Anderson S, Bankier AT, Barrell BG, De Bruin MHL, Coulson AR, Drouin J, Eperon IC, Nierlich DP, Roe BA, Sanger F, Schreier PH, Smith AJH, Staden R, Young IG (1981) Sequence and organization of the human mitochondrial genome. Nature 290, 457-464

Anderson S, De Bruijn HL, Coulson AR, Eperon IC, Sanger F, Young IG (1982) Complete sequence of bovine mitochondrial DNA. Conserved features of the mammalian mitochondrial genome. J Mol Biol 156, 683-717

Bibb MJ, Van Etten RA, Wright CC, Walberg MW, Clayton DA (1981) Sequence and gene organization of mouse mitochondrial DNA. Cell 26, 167-180

Brown WM, George M, Wilson AC (1979) Rapid evolution of animal mitochondrial DNA. Proc Natl Acad Sci USA 76, 1967-1971

Gyllensten U, Wharton D, Wilson AC (1985) Maternal inheritance of mitochondrial DNA during backcrossing of two species of mice. $J$ Hered 76, 321-324

Hecht W, Hiendleder S, Reis A, Dzapo V, Wassmuth R, Herzog A (1988) Analysis of mtDNAs from sheep and pig. In: Proc of the 8th European Colloquium on Cytogenetics of Domestic Animals, Bristol, 19-22 July

Nei M, Li WH (1979) Mathematical model for studying genetic variation in terms of restriction endonucleases. Proc Natl Acad Sci USA 76, 5269-5273

Sambrook J, Fritsch EF, Maniatis T (1989) Molecular Cloning. Cold Spring Harbor Laboratory Press, Cold Spring Harbor, NY

Wilson AC, Cann RL, Carr SM, George M, Gyllensten UB, Helmbychowski KM, Higuchi RG, Palumbi SR, Prager EM, Sage RD, Stoneking M (1985) Mitochondrial DNA and two perspectives on evolutionary genetics. Biol J Linn Soc 26, 375-400 